\title{
Novel drugs in the management of acute mountain sickness and high altitude pulmonary edema
}

This article was published in the following Dove Press journal:

Open Access Journal of Sports Medicine

30 December 2015

Number of times this article has been viewed

\section{Gaurav Sikri \\ Anirban Bhattacharya \\ Department of Physiology, Armed Forces Medical College, Wanowarie, Pune, India}

Correspondence: Gaurav Sikri Department of Physiology, Armed Forces Medical College, Sholapur Road, Wanowarie, Pune 4I I040, India $\mathrm{Tel}+918806709800$ $\mathrm{Fax}+912026334236$ Email drgaurav35@gmail.com

\section{Dear editor}

We read with great interest the review article titled "Wilderness medicine at high altitude: recent developments in the field" by Shah et al. ${ }^{1}$ The authors have comprehensively summarized the recent advances in the field of high altitude medicine relevant to sports and travel medicine. However, Shah et al have described potential drugs for management of high-altitude illnesses, such as acute mountain sickness (AMS), high altitude cerebral edema, and high altitude pulmonary edema (HAPE) as one group under the section "Novel drug treatment for AMS". The pathophysiologies of these two sets of diseases (AMS/high altitude cerebral edema as one and HAPE as another set) are different ${ }^{2}$ and hence it would have been nice to have had the novel drugs described separately to elucidate the therapeutic approach for the two different classes of diseases. Shah et al have highlighted the possible beneficial use of dietary nitrate supplementation (as a source of nitric oxide [NO]) in AMS, but drugs such as inhaled NO and prostaglandin (Iloprost) for HAPE deserve a mention in this list of potential therapeutic agents. ${ }^{3,4}$ Anand et al have suggested significant beneficial effects of inhaled NO in HAPE patients. ${ }^{3}$ Iloprost in combination with $\mathrm{NO}$ has been found to decrease pulmonary arterial pressures in HAPE-susceptible individuals. ${ }^{4}$ Although, the latest guidelines on prevention and treatment of HAPE by the Wilderness Medical Society do not include these drugs, this is probably due to the limited work done on these drugs under field conditions of high altitude. Shah et al have also emphasized on specific phosphodiesterase type 5 inhibitors as potential therapeutic agents for AMS and HAPE. However, an expert panel from the Wilderness Medical Society do not recommend the use of phosphodiesterase type 5 inhibitors for AMS, but the same can be used for prevention (recommendation grade: 1C) and treatment (recommendation grade: $2 \mathrm{C}$ ) of HAPE. ${ }^{2}$

\section{Disclosure}

The authors report no conflicts of interest in this communication.

\section{References}

1. Shah NM, Hussain S, Cooke M, O’Hara JP, Mellor A. Wilderness medicine at high altitude: recent developments in the field. Open Access J Sports Med. 2015;6:319-328. 
2. Luks AM, McIntosh SE, Grissom CK, et al. Wilderness Medical Society practice guidelines for the prevention and treatment of acute altitude illness: 2014 update. Wilderness Environ Med. 2014; 25(4 Suppl): S4-S14.

3. Anand IS, Prasad BA, Chugh SS, et al. Effects of inhaled nitric oxide and oxygen in high-altitude pulmonary edema. Circulation. 1998;98(22): $2441-2450$
4. Maggiorini M, Melot C, Pierre S, et al. Effects of inhaled nitric oxide and prostaglandin on pulmonary hemodynamics in high altitude pulmonary edema resistant and susceptible climbers. In: Roach R, Wagner P, Hackett P, editors. Hypoxia into the next millennium. New York: Kluwer Academic/ Plenum Publishers, 1999;408. 


\section{Authors' reply}

Neeraj M Shah'

Sidra Hussain ${ }^{2}$

Mark Cooke ${ }^{3}$

John P O'Hara ${ }^{3}$

Adrian Mellor ${ }^{3,4}$

'Division of Asthma, Allergy and Lung Biology, King's College London, UK; ${ }^{2} \mathrm{School}$ of Medicine, University College London, London, UK; ${ }^{3}$ Research Institute for Sport, Physical Activity and Leisure, Leeds Beckett University, Leeds, UK; ${ }^{4}$ Academic Department of Military Anaesthesia and Critical Care, Royal Centre for Defence Medicine, Birmingham, UK

Correspondence: Neeraj M Shah

49 Bodley Road, New Malden, Surrey KT3 5QD, UK

Tel +44 7739576 II 5

Email neeraj.shah@nhs.net

\section{Dear editor}

We would like to thank Sikri and Bhattacharya taking the time to consider our review.

We believe our narrative is clear that acute mountain sickness and high altitude pulmonary edema are separate pathologies. The aim of this review was to highlight topical issues around high altitude medicine, not a systematic review of all of the data; thus we elected to group discussion on all novel treatments into a single section on medications.

We accept the theoretical benefits of inhaled nitric oxide (NO) or prostaglandins, but we have tried to focus the review on concepts directly relevant to the journal's readership. The method of delivery of inhaled NO, as described in the studies cited by Anand et $\mathrm{al}^{1}$ and Maggiorini et $\mathrm{al}^{2}$ is not practical outside a dedicated medical facility. Furthermore, the studies cited are over 15 years old. This review is discussing recent advances in the field and as there have not been any further studies conducted on inhaled NO, this did not fall into the remit of our review.

We included discussion about phosphodiesterase type 5 inhibitors as they are topical with recent studies investigating their utility at high altitude, and we believed the journal readership are likely to be asked about these. We have not contradicted published guidance on the use of phosphodiesterase type 5 inhibitors, but have discounted any recent evidence for their use.

\section{Disclosure}

The authors report no conflicts of interest in this communication.

\section{References}

1. Anand I, Prasad B, Chugh S, et al. Effects of inhaled nitric oxide and oxygen in high altitude pulmonary edema. Circulation. 1998;98(22): 2441-2450.

2. Maggiorini M, Melot C, Pierre S, et al. Effects of inhaled nitric oxide and prostaglandin on pulmonary hemodynamics in high altitude pulmonary edema resistant and susceptible climbers. In: Roach R, Wagner P, Hackett P, editors. Hypoxia into the next millennium. New York: Kluwer Academic/Plenum Publishers, 1999;408

Dove Medical Press encourages responsible, free and frank academic debate. The content of the Open Access Journal of Sports Medicine 'letters to the editor' section does not necessarily represent the views of Dove Medical Press, its officers, agents, employees, related entities or the Open Access Journal of Sports Medicine editors. While all reasonable steps have been taken to confirm the content of each letter, Dove Medical Press accepts no liability in respect of the content of any letter, nor is it responsible for the content and accuracy of any letter to the editor.

\section{Publish your work in this journal}

Open Access Journal of Sports Medicine is an international, peer-reviewed, open access journal publishing original research, reports, reviews and commentaries on all areas of sports medicine. The manuscript management system is completely online and includes a very quick and fair peer-review system.
Visit http://www.dovepress.com/testimonials.php to read real quotes from published authors. 